a century, contended that a definition of race more in accord with realities was an urgent necessity. In even the most inbred populations there were family lines of descent which included different genetic characters, while in every family line were frequently included individuals of most diverse genetic types. There was, he maintained, no population which from the racial point of view was so uniform as to be considered either anatomically or physiologically a unity. The different groups of the white races so far resemble one another that often extremes of the same type are more diverse than the means of two different types. He stressed the influence of environment, and showed how, in the United States, attitude and gesture, which have been said to be determined by race, were modified in the American-born descendants of immigrants.

Prof. J. Brutzkus dealt with the racial bearing of his research on the blood groups of Jews, which he said pointed to a differentiation of four types: Semitic, Western European, Mixed Eastern European and Mongoloid. Further, this differentiation corresponds with the differentiation of head-form. The diversity of Jewish types is due on one side to the crossing of the Semitic type with the proselytes of the Roman Empire, and on the other with those of the Khozar. He maintained that according to the evidence of the blood group the Jews of Berlin are more purely European than the Germans themselves, while the Jews of the Crimea and the Caucasus are more purely Asiatic than the autochthonous Tartars.

The fundamental principle of racial doctrines was attacked by Dr. '/sollschan of Prague, who maintained that recent research among the most remote peoples in Europe and the most primitive in other parts of the world had shown that the doctrine of the persistence and immutability of racial type was untenable. The claim to a superiority of racial type was based on the desire to dominate. In conclusion, he suggested a world-wide collaboration of scientific institutions, concentrating on the investigation of the problems of race.

This proposal was strongly condemned by Prof. J. Thurnwald of Berlin, who maintained that no man of science was capable of considering any scientific problem whatsoever without importing into his con. clusions elements which were the immutable outcome of his race.
Considerable discussion was also aroused by a communication from Dr. Ritter on the racial composition of the gipsies of Central Europe, in which it was shown that their mixed racial character justified the measures of 'purification' which had been taken by the Third Reich. This contention was opposed by Dr. Brutzkus, who maintained that the "Bohemians" were the most authentic and the purest descendants of the Aryan race.

Debate became particularly lively in discussion of the report on "The Eugenics of Mental Disease", presented by Prof. Rüdin, in which the necessity was urged for the sterilization of all persons known to be affected by hereditary disease. Prof. Schneerson argued in opposition that it had been proved that certain men of genius descended from families subject to hereditary disease, while they themselves were often abnormal, quoting the cases of Dostoiewski and Nietzsche. The doctrine of mental eugenics meant the elimination of outstanding personalities and in the end the lowering of the intellectual standard of humanity. The increase in mental disease, notwith standing the progress of medical science, was due to the increased nervous tension of modern life, and suggested a remedy in the improvement of material and social conditions. The surest eugenic measure was the instinct of love. Any other detracts from the dignity of man and deprives him of all his faculties of intellectual and moral progress. The proposals of the report were also criticized by Prof. Beck of Prague, who pointed to the contradiction inherent in the application of all racial doctrine and theories of "the blood", which while imputing insubordination to the law of the blood, maintained that a blind racial destiny imposed a determinism, which denied freedom of will to adopt such measures of eugenics as would foster the intellectual advancement of the species - the voluntaryist conception of the problem.

Among other communications may be mentioned Mme. Haiser (Amsterdam) on the effects of environment on the sounds of languáge, and Dr. Schreider's report on biometric investigations among the Otomi of Mexico. The proceedings of the section closed with a full session devoted to consideration of a masterly report by Mlle. Weinberg on "Differential Biometry and Biotypology in the Classification of Individuals and Groups".

\title{
The Central (Native) Medical School, Suva, Fiji
}

\section{By Sir James Barrett, K.B.E:}

\begin{abstract}
$\mathrm{T}$ HE major problem in the attempt by a civilized nation to develop people who, by our standards, are regarded as backward, is the control of disease and the preservation of health.

It is difficult of solution for several reasons. The native is not inclined to co-operate, as he does not understand-and finds it difficult to understandthe mode of thought and the technique of the European medical officers. The employment of many European medical officers is economically impossible, hence the training of the native himself is essential. Knowing the language, customs and mode of thought of his countrymen, he can effect changes which otherwise would be out of the question. For these reasons the Central (Native) Medical School at Suva,
\end{abstract}

Fiji, furnishes a great object lesson, since it repre. sents a sincere and successful attempt to apply the principles of Western medicine to Polynesians, Melonesians and (now) Indians in the South Pacific. Like most British institutions, the growth has been gradual and the adaptation to needs has been effected as occasion arose.

The Principal Medical Officer in Fiji in 1885-Dr. Coney-obtained the passage of an ordinance providing that any native student who had received hospital training and practice for three years and been examined in medicine and surgery might be enrolled as a native medical practitioner. There was no medical school building and the training was effected at the Colonial Hospital, Suva. In 1900 a 
lecture room and a hostel for the residence of students were built, and with diagrams, models, text.books and lectures a more comprehensive system was organized. At this date there were about twenty practitioners. In 1918 there were forty-eight, who did fine work in the influenza epidemic of that year, but during which eight of them lost their lives.

In 1923 the hospital was rebuilt and re-organized and called the Colonial War Memorial Hospital, and with subsequent development has become an excellent and extensive institution. Students from other Islands than the Fiji group were admitted and the School became a central school for the Western or Southern Pacific.

At this stage Dr. Montague was Chief Medical Officer, and in co-operation with Dr. Lambertdirector of the Rockefeller Foundation in the South Pacific - a notable development took place. A School was built with the generous aid of the Foundation, containing lecture rooms, dissecting rooms, chemical and physiological laboratory, library and museum. Accommodation was provided for forty resident students. Quite recently the Foundation has given an excellent pathological, bacteriological and biochemical block and a post-mortem theatre. It is hoped that this laboratory will become the centre of investigation for scientific study in the South Pacific. The staff of the School consists of a wholetime tutor and fourteen honorary lecturers. The teaching in the old school was in the Fijian language. In the new school good knowledge of English is required of all students, and an entrance examination on the basis of the New Zealand proficiency examination is required. The course of study until 1931 was of three years' duration, but it was then increased to four years' and post-graduate courses came into existence.

Whilst this development has taken place, the training of native nurses was organized on a threeyear basis, and in 1935 there were fifty-five nurses in the department and stationed throughout Fiji. It is hoped to make the hospital a central School for Nurses in the South Pacific by similar methods to those adopted in the Central Medical School. Such then is the mechanism of this really useful institution.

The students are divided into two groups-junior and senior. The junior course occupies $1 \frac{1}{2}$ years and the senior course $2 \frac{1}{2}$ years. The junior course covers chemistry, physics, biology, anatomy and physiology with some voluntary out-patient hospital work. The senior course includes medicine, surgery, public health and the smaller clinical subjects, including the study of diseases of children, diseases of the eye and some dentistry. The number of students in 1935 and their source is set out in the accompanying table:

$\begin{array}{lrrrrrr} & \begin{array}{c}\text { 1st } \\ \text { year }\end{array} & \begin{array}{c}\text { 2nd } \\ \text { year }\end{array} & \begin{array}{c}\text { 3rd } \\ \text { year }\end{array} & \begin{array}{c}4 \text { th } \\ \text { year }\end{array} & \begin{array}{c}\text { Post- } \\ \text { graduates }\end{array} & \text { Total } \\ \text { Western Samoa } & 3 & - & - & 1 & - & 4 \\ \text { Eastern Samoa } & 1 & - & - & - & - & 1 \\ \text { Tonga } & 1 & - & 1 & 2 & - & 4 \\ \text { Gilbert and Ellice } & & & & & & \\ \quad \text { Islands } & 1 & - & 1 & 2 & 1 & 5 \\ \text { Solomon Islands } & 1 & 1 & 1 & 1 & - & 4 \\ \text { New Hebrides } & - & 1 & - & - & - & 1 \\ \text { Nauru } & 1 & - & - & - & - & 1 \\ \text { Cook Islands } & 2 & - & - & 1 & - & 3 \\ \text { Giji-Fijians } & 4 & - & 5 & 5 & 1 & 15 \\ \quad \text { Rotumahans } & - & - & 2 & - & - & 2 \\ \quad \text { Indians } & 1 & - & 1 & - & - & 2 \\ \quad & 15 & - & - & - & - & 42\end{array}$

During the year there were 40 students in residence at the two dormitories. The two post-graduates in the above list are qualified native medical practitioners, and do not reside in the students' dormitories. The 12 Fijian students who reside in the smaller dormitory are required to keep their rooms and grounds in good order. The remaining 28 students who live in the large dormitory are expected to keep their own bedroom tidy and clean, but an Indian servant is provided to assist in the general management of the other rooms and the surrounding grounds. The students' dining-room is in the large dormitory, so that during the continuous rainy weather, which lasted for about six months during 1935, the Fijian students were put to great inconvenience as the two dormitories are about a quarter of a mile apart.

Recently Dr. Hoodless, the medical tutor, in answer to some questions of mine, furnished the following information :

Roughly, the 40 students at present (October, 1936) at the Central Medical School, include 19 Polynesians, 6 Melanesians, 6 mixed Polynesian and Melanesian, 7 mixed European and Polynesian and Melanesian, and 2 East Indian. The Polynesian students win most of the prizes at class and yearly examinations, but this is due to their numerical ratio, 19 out of 40 students : and also due to the fact that the mission and Government schools in the Poly. nesian islands are much superior to those in the Melanesian islands, so that the Polynesian students enter the Medical School with a very satisfactory preliminary education while the pure Melanesian students come here with very little elementary education. Indian students generally speaking are very good at book learning, but they do not make the same success at practical work. For steady regular work and good progress in medical knowledge, the mixed type of student, part Polynesian, is perhaps the most successful of all, but here again there are other factors at work.

Supervision of the students when they return to their own Islands is entirely in the hands of the local administrations. For Tonga, the Gilbert and Ellice Islands, and the Solomons, the native medical practitioner ordinances in each Administration can be controlled from Fiji through the Western Pacific High Commissioner, who is also Governor of Fiji. For Eastern Samoa (U.S.A.), Western Samoa (N.Z.), Cook Islands (N.Z.) and the New Hebrides (Fr. and Brit.) the position is different. The success of the native medical practitioner system in each of these Administrations depends on : $(a) \mathrm{A}$ sympathetic understanding and control from the Administration concerned. (b) A close personal and very sympathetic understanding from the European medical officers in any of these Administrations in regard to the native medical practitioners sent back from Suva to that Administration. (c) A continuously developing esprit de corps among all the qualified native medical practitioners far and wide in the South Sea Islands. This is obtained through the N.M.P. Journal, personal correspondence, and occasional post-graduate courses.

Pensions have been granted for retired native medical practitioners in Fiji only. The native medical service is only a few years old in the other Administrations, and the question of retirement on pension has not yet arisen, nor is it likely to arise for another fifteen years or more. It is anticipated that pensions will be granted in Tonga and in Western 
Samoa, but in the other Administrations it is probable that increased salary and allowances will be given during the actual period of service and that no pensions will be granted.

The native medical practitioners receive salaries varying from $£ 60$ to $£ 150$ per annum, which apparently meet their wants adequately. They are medical officers and do not seek private practice as we understand it. Their journal, The Native Medical Practitioner, is an excellent publication which will interest any European practitioner.

In the Tropical Diseases Bulletin of November 1936 a detailed account of the working of the Central School is published by Dr. Clunie (Medical Superintendent of the Colonial War Memorial Hospital, Suva) and Dr. McGusty (late Inspecting Medical Officer, Fiji). The Islands served contain about 500,000 people, and at present there are 84 medical practitioners distributed as follows: Fiji 56, Samoa (Western) 9, Samoa (Eastern) 0, Tonga 4, Cook Island 2, Gilbert and Ellice 10, Solomon Islands 2, New Hebrides 1, total 84 ; native obstetric nurses, Fiji, 47.

Their conclusion is as follows : "Taken individually the Administrations participating in the Native Medical Practitioner scheme have not the means to embark on elaborate enterprises to provide adequate medical services, but by a pooling of their resources, as is now the case at the Central Medical School, it is felt that they will be able to elaborate a common form of health organization that will bestow further benefits on the native peoples. In Fiji the system has proved successful after a long and searching trial, and if it is too early yet to claim the same success with regard to its more recent ramifications into the other Pacific Administrations, the similarity of conditions and the favourable reports that are coming to hand appear to provide full justification for the confidence which those of us who are in the closest touch feel with regard to the future of the Native Medical Practitioner in the Pacific. As the system becomes more permanently established everywhere it will suffer progressively less from the effects of destructive criticism, but there will always remain the danger that some over-enthusiastic supporters may lose sight of the fundamental cause of its success and in a misguided attempt to raise the status of the Native Medical Practitioner may defeat the purpose for which the school was created, namely to make a health service available to these native peoples at a low cost and in the form that is most easily assimilable by their society."

The School is administered economically, the average cost per student being about $£ 75$ per annum; that is, total cost about $£ 3,000$ per annum. Amongst the many tributes to the efficiency of the School place must be given to the observation of Prof. Buckmaster and Dr. Wright made after a visit to the School when returning to England in 1931 from Australasia. Their comment was as follows: "The Hospital and Medical School at Suva for Natives of Fiji, Samoa and Other Tslands is really a wonderful place to find in the South Pacific. We not only saw all over the Hospital, but conducted a short class in anatomy and physiology in the School and both thought the students equal to what we might have expected to find in an ordinary Medical School in London. Indeed we were both astonished at the information they had acquired. I ask how many Englishmen know anything about this remarkable Hospital in Fiji ?"

In conclusion I have one caution to emphasize. If enthusiastic people try to extend the course and to increase the expense, much damage may be done in seeking something economically impossible. There is, I am glad to say, no evidence at present of any such intention. Depopulation has ceased in Fiji and with prudent administration the Central School may prevent depopulation in the other Islands. I am very grateful to Dr. A. H. B. Pearce, Principal Medical Officer, Fiji, and his staff for the information furnished on several visits, for the personal contact obtained with these fine young men and for many reports.

\section{The Radio Exhibition at Olympia}

\begin{abstract}
$7 \mathrm{HE}$ annual radio exhibition at Olympia, which this year was held on August 25-September 4, is generally a partial disappointment to those interested in the scientific and technical aspects of broadcasting, as it is usually quite difficult to ascertain what technical progress and improvements are being displayed. The exhibition is largely an elaborate display of the external cabinets, although most firms nowadays provide simple means for inspecting the internal construction and layout of the receiver itself. This year there was abundant evidence to show that most manufacturers have realized that the modern broadcast receiver has to take its place as an article of domestic furniture, and as such it must not be made especially conspicuous by its curious shape and appearance. Another notable advance in what may be termed the external features of the receiver is constituted by the enlargement of the tuning scale and its ease of operation. There is, however, still room for greater uniformity in the location of the control knobs among receivers of different makes.
\end{abstract}

In order to appreciate the improvements made in the internal portion of broadcast receivers, the visitor to the exhibition was fortunate in having as a guide the detailed reports given by such technical journals as the Wireless World, which has published three special show numbers on this occasion. A general survey of this year's exhibits of the various manufacturers indicates that many fundamental features of the broadcast receiver have become sufficiently stabilized for the designer to concentrate upon the steady improvement of detail. The great majority of receivers now manufactured are of the supersonic heterodyne type, since this provides both the sensitivity and the selectivity required by modern broadcasting conditions. The selectivity has now generally been made adequate by the incorporation of a properly tuned amplifying stage operating at the incoming signal frequency. A noteworthy advance this year is the incorporation of a correctly designed short-wave range as a standard feature; and the division of the short-wave broadcasting band into 